$\xi=-1$

\title{
Price and Marketing Information in Chili Farmers Communica- tions Network in Indonesia
}

\author{
Dyah Gandasari and Achmad Musyadar \\ Bogor Agriculture Extension College, Bogor, West Java, Indonesia
}

\begin{abstract}
Fluctuations in price and the nature of chilli that can easily damaged lead to chili farmers need accurate and reliable information to improve its marketing. It is interesting to study the communication network of chili farmers in the process of collecting information on the price and marketing. The purpose of this research is to analyze the communication network of price and marketing information of the chilli farmers in Pacet District of Cianjur Regency, West Java Indonesia. The communication network is analyzed using UCINET 6 analysis tools and individual analysis unit. The results of the study shows that: 1) the communication network structure is centralized or interlock personal network, 2) the source of information (star) is the chairman of the farmers group or farmers group association who works as a trader, 3) the average values of out-degree and in-degree is about 1.276 and 1.394.
\end{abstract}

Keywords: Local Centrality, Global Centrality, Star, Out Degree, In Degree

\section{Introduction}

Generally, horticulture commodities such as chili are easily damaged. Chili can not be stored for long time, so that it must be sold and consumed immediately. Therefore, careful planning of chili production and appropriate information are required in the agribusiness of chili. Otherwise, farmers will become the object of the sharp price fluctuation.

In order for chili farmers to be able to handle various challenges and uncertainties such as price fluctuations and market access, information management is needed as input to deal with the uncertainty (Flor and Matulac 1994 in Lubis 2000). Sufficient and reliable information is needed in improving product marketing. In the search for information, farmers must build a network structure with neighbors and other sources of information (Littlejohn \& Foss 2009). The structure of the network can describe how farmers' communications behavior in receiving, giving and disseminating information. Thus, the research on chili farmers' communication network is important to see the existing strength structures in marketing their products.

In fact, certain obstacles are found that tend to inhibit the smoothness in improving the business such as access and inadequate information management. The previous studies have found that obstacles encountered include access to information (Setiawan 2008, Fuady et al. 2012, Zulkarnain 2015, Gandasari et al. 2015a, Raharjo 2016), market access among actors (Indraningsih et al. 2001, Raharjo 2016, Amiruddin 2016), access to market information and information control by one actor (Rangkuti 2007, Utami 2013), lack of information in the agribusiness development (Bulkis 2013, Bulkis 2015, Hapsari 2012).

The objective of the study is to analyze the communication network of chilli price and marketing information that formed among farmers as an effort to reduce uncertainty in marketing of chili.

\section{Theoritical Background}

This study refers to the concept of convergence communication model by Rogers and Kincaid (1981). The convergence communication model defines communication as the process by which communication participants create and share information with each other in order to achieve common meaning. According to Kincaid (1979) in Rogers and Kincaid (1981) on of the the main components in this model is network connectivity. In this study, aspects of the study of communication networks include the role of individuals and indicators of communication networks.

The role of the individual is shown by its role as a star in the social system. Some research on the role of individuals in the network such as Setiawan (2008), Gustina et al. (2008), Gandasari et al. (2015a, 2015b), Zulkarnain et al. (2015), Bakti et al. (2015), Cindoswari (2016), Anggriyani (2014), Wahyuni (2017), Yusi (2013) and Pangestu (2015) and Wardyaningrum (2016).

The network indicator used in this study refers to the measurement according to Freeman (1979) in Scott (2000) which consists of local centrality and global centrality. Local centrality is chosen because it can give an idea of a person's ability to build relationships with other individuals in the social system in the environment around himself. The global

centrality is selected because it can describe a person's abilityto access all the individual members of the system as a whole. Allegedly the higher the level of ability of farmers in contacting other individuals or other sources of information both in neighboring systems and in the overall system, the better marketing done by the farmer. 


\section{Method}

This research uses a descriptive quantitative approach. The study used survey and samples design with 100 respondents of chilli farmers in Pacet District, Cianjur Regency, West Java. Cianjur was selected as sampling location because it is one of the chili production center in Indonesia. The results obtained in the form of sosiogram using NetDraw visualization and measurement results to the degree of centrality measurement, namely: local centrality and global centrality. The Ucinet 6 analysis tool is used to assess the communication activity of chili farmers. The unit of analysis studied is individual.

\section{Results and Discussion}

\section{Communication network on Price information}

The result of the study shows that in collecting chili price information, as many as 28 respondents asked fellow farmers, 59 respondents asked the farmers who also work as traders, 48 respondents asked businessmen/middlemen/merchants, 15 respondents asked officials/local counselor, and 1 respondent asked the restaurant agent. This means that there are still many farmers who communicate in the collection of information on chili prices outside the system, especially to business actors/mid-

dlemen/merchant collectors. This illustrates the weak institutional structure of farmers.

The communication network of chili price information describes a centralized structure or an interlock personal network. This happens because there is a dominant role of more capable individuals in communication networks. Some of the previous studies that illustrate the centralized structure are Utami 2013 and Zulkarnain 2015.

Farmers who have a role as a source of information in the communications network sociogram shown by nodes that have the highest degree of connectivity or called a star. Figure 1 illustrates that in Ciputri and Ciherang villages, individual who acts as a star is Actor 4. In Cipendawa Village, the individual who acts as a star is Actor 42, Actor 43 and Actor 135. In Cibodas Village, there is no individual acts as a star because many individuals contacted by these members are individuals outside the system, namely Actor 123. In Sukatani Village, the individual who acts as a star is Actor 139.

Actor 4 is the chairman of the Mandiri Farmers Group and the Chairman of the Putri Kencana Farmers Group Associatin of Ciputri Village. Beside of working as farmer, Actor 4 also works as a trader supervised by the Center for Food Crops and Horticulture Development (Balai Pengembangan Budidaya Tanaman Pangan dan Hortikultura / BPBTPH) Kecamatan Pacet with the market target of traditional markets. In addition, the farmers contacted Actor 4 to ask about the vegetables price because he is very active and ease to be found, so that the communication can occur directly or face to face.

Actor 42 is the chairman of the Mulya Tani Jaya Giri Farmers Group and also the chairman of Jaya Mulya Tani Jaya Giri Farmers Group Association Cipendawa Village. In addition to working as a farmer, Actor 42 also works as a trader with partnerships with supermarkets and restaurants as well as partners of the Directorate General of Horticulture (Champion) Cianjur Regency in supplying chili to Jakarta and other big cities in West Java. As a Champion farmer in Cianjur, Actors 42 has the task of maintaining supply and price stability in Cianjur regency and set the pattern of planting in the supervised groups. This also causes the actor 42 to have information about the price of chilli more than other farmers. In addition he also has broad knowledge.

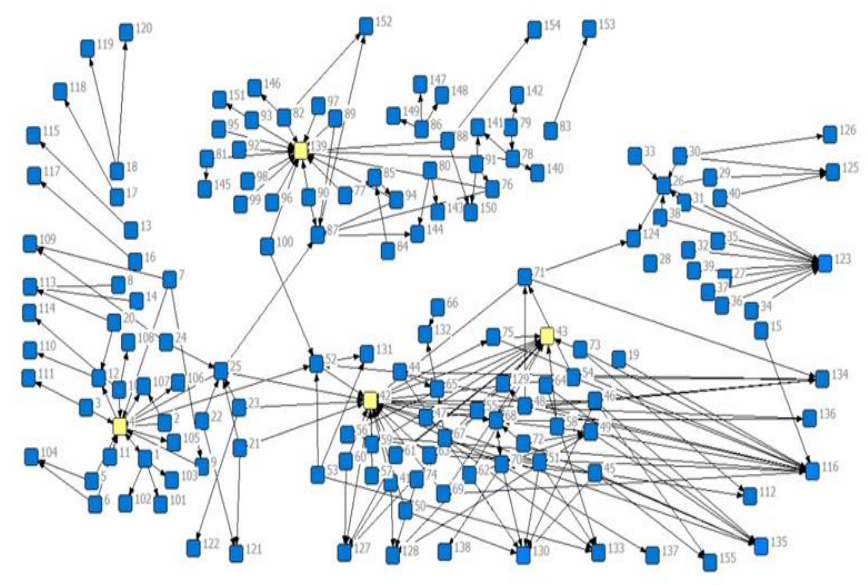

Fig. 1. Price Information in Chili Farmers Communication Networks

Actor 43 is the chairman of the Giri Lestari Farmers Group Cipendawa Village. The farmers contacted Actor 43 to ask about the price of chili because he is an active individual. In addition to being the main actor, Actor 43 is an official in Cipendawa Village Government. The facilities often used by the Actor 43 in communicating with other farmers are the means to send messages (SMS and WhatsApp).

Actor 135 is the chairman of the Agrosegar Farmers Group in Ciherang Village. Besides as the main actors, Actor 135 is also a business actors supervised BTBTPH Pacet District with the target market of modern markets. Actor 135 sells his products to supermarkets, hotels and restaurants. The farmers contacted Actors 135 to ask about the chili price because of his friendly and sociable attitude.

Actor 139 is the chairman of the Surya Kencana Farmers Group Association Sukatani Village. Actor 139 has a very wide market network for the modern market because in addition to selling his own products, he also manage sales for farmers group association members under his coordination.

Analysis of communication networks at the individual level in this study is used to see the size of local centrality and global centrality of chili farmers. The value of centrality based on the topic of information on the price of chili in communication networks can be seen in Table 1.

The actor who have the highest out degree value in the price information of chili is Actor 4, namely the chairman of the Mandiri farmers group and the chairman of the Putri Kencana Farmers Group Association Ciputri Village. Actor 4 is most often keep contact with many people and knows or has information about who the actors are being the source of information.

The actor who has the highest in-degree value on the information of chili price is Actor 42, that is the chairman of Mulya Tani Jaya Giri farmers group and farmers group association Cipendawa Village which is the Champion of Cianjur Regency. The actor is most often used as a place to ask by many people or become a star. The average out degree and in degree of 1,394 means low connectivity. Farmers in communications networks only communicate the information about the price of chilli only to the source of information or called "star", so the role of the Star becomes very important. Farmers do not share much information or discuss it with other farmers.

The global centrality of communication network of chili price information shows the infarness of Actor 42 and outfarness of Actor 4 . It means that the fastest farmer can be contacted by other farmers in the network is Actor 42, that is the chairman of Mulya Tani Jaya Giri farmers group associ- ation Cipendawa Village. The fastest actor to disseminate information obtained from information sources is the Actor 4, that is the chairman of the Mandiri farmers group and also the chairman of the Putri Kencana farmers group Ciputri Village. 
Table 1. The value of local centrality and global centrality of chili farmers in Pacet District based on communications network topics concerning price information

\begin{tabular}{|c|c|c|c|c|}
\hline & \multicolumn{2}{|c|}{ Local Centrality } & \multicolumn{2}{c|}{ Global Centrality } \\
\hline inDegree & $\begin{array}{c}\text { outDe- } \\
\text { gree }\end{array}$ & inFarness & outFarness \\
\hline Averge & 1.394 & 1.394 & 23002.199 & 23002.199 \\
\hline $\begin{array}{c}\text { Maxi- } \\
\text { mum }\end{array}$ & 21.000 & 6.000 & 23870 & 23870 \\
\hline $\begin{array}{c}\text { Mini- } \\
\text { mum }\end{array}$ & 0.000 & 0.000 & 16430 & 19610 \\
\hline
\end{tabular}

\section{Communication Network on Chili Marketing}

The result of the study shows that in collecting information on chili marketing, 41 respondents asked fellow farmers, 44 respondents asked farmers who also work as traders/middlemen/collector traders, 61 respondents asked business actors/middlmen/collector traders, 12 respondents asked local officials/counselors, and 2 respondents asked the restaurant agent. This means that most farmers communicate in collecting information on the price of chili outside the system, especially to the middlemen/collector traders. This illustrates the fragile structure of farmers institutions. The information on chili marketing is still dominated by middlemen/collector traders.

Communication network on chili marketing information describes a central or interlock personal network structure. This means that there is a dominant role of more capable individuals in communication networks.

The sociogram in Figure 2 indicates some actors acting as stars. In Ciputri and Ciherang villages, individual acting as star is represented by Actor 4. In Cipendawa Village, the individual who acts as a star are represented by Actor 42 and Actor 43. In Cibodas Village, there is no individual who becomes a star, this is due to individuals who is contacted by many of these members is individual outside the system, namely Actor 115. In Sukatani Village individual who act as star is represented by Actor 140. Actor 42, Actor 43 and Actor 140 are the chairmans of farmers groups / farmers groups association. Beside of working as traders, they are also managing the sales of their group members. This also causes them to have a very wide marketing network and information about chilli marketing more than other farmers. In addition, these actors are individuals whose knowledge is broad and communicative.

Actors outside the system as the sources of information are Actor 115, Actor 108, Actor 118, and Actor 122. Actor 115 is a middleman/collector trader in Cibodas Village. Actor 115 controls information about the quality and quantity of products required by the market. The farmers contacted the Actor 115 to inquire about the chillies marketing because he plays role in controling information, having extensive communication networks, experienced, and consistent and sociable personality Actor 108, Actor 118 and Actor 122 are middlemen/collector traders in Cipendawa Village who have information about the quality and quantity of products required by the market. The farmers contacted Actor 108, Actor 118, and Actor 122 to inquire about the chili marketing aside because they are controlling the information, they are also humorous, sociable, friendly yet firm individuals. They are actively seeking information from fellow traders and collector farmers by phone or meet directly to sell the chilies.

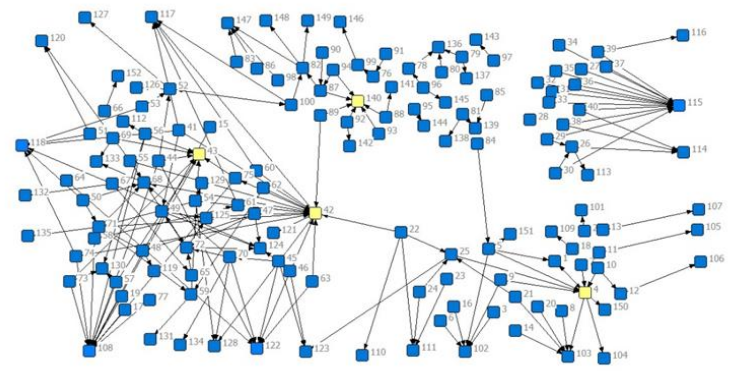

Fig. 2. Marketing Information in Chili Farmers Communication Networks
The analysis of individual-level communication networks in this study is used to see the size of local centralities and the global centrality of chili farmers based on the topic on chili marketing in communication networks (Table 2).

The actor with the highest out degree and in degree score is Actor 42. It means that the actor is the most influential and the source of information for other farmers. Actor 42 is the chairman of Mulya Tani Jaya Giri farmers group as well as the farmers group assoiation Cipendawa Village as Champion of Cianjur Regency. He has broad knowledge and network with outsiders of his group.

The average out degree and in degree of 1,276 means low connectivity. Farmers in communications networks only communicate information about the price of chilli only to the source of information called "star", so the role of the star becomes very important. Farmers do not share much of the in-formation or discuss it with other farmers.

The global centrality of information communication network on chili price information shows the infarness and outfarness of Actor 42. This means that Actor 42 is the fastest farmers can be contacted by other farmers in the network and the actor who quickly disseminate information obtained from information sources. Actor 42 is the chairman of Mulya Tani Jaya Giri farmers group and its farmers group association Cipendawa Village.

The result of identification of information source on both networks shows the star is represented by group leader. This study is in line with Prell's theory (2013) which stated that individual with the highest degree of centrality can be iden- tified as leader. This is also in line with previous research that shows the group leader is still the main direction of information dissemination (Anggriyani 2014, Wahyuni et al. 2016, Wahyuni 2016, Wahyuni et al. 2017). However, it is not in line with Malinick's et al. findings (2013) which indicated that formal leader did not occupy a central position in the network

The sources of information both inside and outside the system are actors who have the power of information in the field of marketing, be active, and have the ability to communicate. The findings of some study on networks show

that individuals who are the source of information in communication networks are individuals who have experience and knowledge in their field (Cindoswari 2012 and Saleh 2006, Gandasari et al. 2015b), not reluctant to share knowledge and knowledge, actively participate in groups or social organizations in their environment (Gandasari et al 2015b, Cindoswari 2012 and Saleh 2006), and have the ability to communicate (Gandasari et al 2015b). Personality affects the structure and position in the network (Selden \& Goodie 2018).

The communication is conducted not only face to face but also using communication media. Findings on cassava commodity research (Cindoswari 2012) shows that the communication is still conducted verbally and face to face; and the study on beef cattle commodities (Saleh 2006) shows that communication is also conducted verbally and face to face despite there is a shifting to use communication media.

Average out degree and in degree of 1 means low connectivity. Farmers in communication networks only communicate about price information and marketing of chilli only to the source of information called "star", so the role of star becomes very important. Farmers do not share much of the information or discuss it with other farmers. Enhanced connectivity is necessary because high local centrality will improve the quality of information, quantity of information and process satisfaction (Gandasari et al 2015c). 
Table 2 The value of local centrality and global centrality of chili farmers in Pacet District based on communication network topics concerning marketing

\begin{tabular}{|c|c|c|c|c|}
\hline & \multicolumn{2}{|c|}{ Local Centrality } & \multicolumn{2}{c|}{ Global Centrality } \\
\hline Index & inDegree & $\begin{array}{c}\text { outDe- } \\
\text { gree }\end{array}$ & inFarness & outFarness \\
\hline Average & 1.276 & 1.276 & $\begin{array}{c}22435.98 \\
6\end{array}$ & 22435.986 \\
\hline $\begin{array}{c}\text { Maxi- } \\
\text { mum }\end{array}$ & 14.000 & 5.000 & 22952 & 22952 \\
\hline $\begin{array}{c}\text { Mini- } \\
\text { mum }\end{array}$ & 0.000 & 0.000 & 18606 & 19662 \\
\hline
\end{tabular}

\section{Conclusions}

Source of information on communication network of price information and marketing of chilli is farmer who is chairman of farmers group / farmers group association who also work as a trader, while the source of information outside the system is the middleman / collector trader.

The information exchange network between chilli farmers and middlemen / collector traders is still quite high. This means that most farmers still communicate in the collection of price information and marketing of chili to the outside of the system, that is to the middlemen / collector traders. Chili marketing information is still dominated by middlemen / collector traders.

The average out degree and in degree between 1.276 and 1.394 means low connectivity. Farmers in communication networks only communicate about price information and marketing of chilli only to the source of information / star. Farmers do not share much of the information or discuss it with other farmers.

Low connectivity and information exchange network between chilli farmers and middlemen / collector traders is still quite high. Chili marketing information is still dominated by middlemen / collector traders. This illustrates the farmers' institutional structure in marketing their products is still fragile.

\section{Recommendation}

Chili is one of the horticultural commodities that can be a source of income for the community as well as serve as a quite important center of economic growth. To improve the role of the agricultural sector and become an important economic center, it requires quality and reliable human resources who have managerial, entrepreneurial and business organization management skill. Therefore, the communication network as a social capital is worthy to be considered in the chili farmers empowerment program and strengthening its institutional structure. So that the actors of agricultural development can build a highly competitive business.

\section{References and Notes}

[1] Anggriyani E. Jurnal Sains Peternakan Vol. 12 (2), September : 107-113 (2014)

[2] Amiruddin S. Jurnal Komunitas, Volume 6, Nomor 1, 106-105 (2016).

[3] Bakti I., Priyatna C.C., Novianti E., Budiana R. Jurnal Edutech, Tahun 14, Vol.1 No.3, Oktober (2015).

[4] Bulkis. Jaringan Komunikasi dan Perilaku Petani Sayur [tesis]. Bogor : Institut Pertanian Bogor. (2013)

[5] Bulkis. Jurnal Matematika, Saint dan Teknologi, Volume 16, Nomor 2, September 2015, 28-42 (2015).

[6] Cindoswari A.R. Jaringan Komunikasi dalam Penerapan Teknologi Produksi Ubi Kayu. Kasus Petani Ubi Kayu di Desa Sukobinangun, Kecamatan Way Seputih, Kabupaten Lampung Tengah, Propinsi Lampung [tesis]. Bogor: Institut Pertanian Bogor. (2012)

[7] Fuady I., Lubis D.P., Lumintang R.W.E. Jurnal Komunikasi Pembangunan. Juli 012 Vol. 10 No.2: 10-18 (2012).

[8] Gandasari D., Sarwoprasodjo S., Ginting B., Susanto D. Jurnal Agro Ekonomi, Volume 33 Nomor 1, Mei 2015: 35-50 (2015a).
[9] Gandasari D, Sarwoprasodjo S., Ginting B., Susanto D. Mimbar: Jurnal Sosial dan Pembangunan. Volume 31, No.1, Tahun 2015: $81-91(2015 b)$

[10] Gandasari D., Sarwoprasodjo S., Ginting B., Susanto D. Pertanika Journal Social Sciences \& Humanities. 23(2): 325-337 (2015c).

[11] Gustina A., Hubeis A.V.S., Riyanto S. Jurnal Komunikasi Pembangunan 6(1):72-89 (2008).

[12] Hapsari D.R. 2012. Pemanfaatan Informasi oleh Petani Sayuran Kasus Desa Ciaruten Ilir, Kecamatan Cibungbulang, Kabupaten Bogor [tesis]. Bogor : Institut Pertanian Bogor. (2012)

[13] Indraningsih K.S., Saptana, Hastuti E.L. Jurnal. Bogor : Pusat Analisis Sosial Ekonomi dan Kebijakan Pertanian (2001).

[14] Littlejohn S.W., Foss K.A. Teori Komunikasi. Jakarta. Salemba Humanika. (2009)

[15] Lubis D.P. Communication and Socio-cultural Determinants of Social and Physical Adaptability among Indonesian Transmirant [disertasi]. Los Banos : University of The Philippines (2000)

[16] Malinick T.E., Tindall D.B., Diani M. Social Network. Volume 35, Issue 2, pages 148-158 May (2013).

[17] Prell C. Social Network Analysis: History, Theory\& Metodology. Singapore: SAGE (2012)

[18] Pangestu M. Jurnal e-Komunikasi Vol 3. No.2 (2015)

[19] Raharjo A. Komunikasi Pemasaran Kakao di Kecamatan Anreapi Kabupaten Polewali Mandar, Provinsi Sulawesi Barat [tesis]. Bogor : Institut Pertanian Bogor (2016).

[20] Rangkuti P.A. Jaringan Komunikasi Petani dalam Adopsi Inovasi Teknologi Pertanian [tesis]. Bogor : Institut Pertanian Bogor. (2007).

[21] Rogers E.M., Kincaid L. Communication Network: Toward a New Paradigm for Research. London (BG): Collier Macmilan Publisher (1981).

[22] Saleh A. Tingkat Penggunaan Media Massa dan Peran Komunikasi Anggota Kelompok Peternak dalam Jaringan Komunikasi Penyuluhan [disertasi]. Bogor : Institut Pertanian Bogor (2006).

[23] Scott. Social Network Analysis: a Hand Book. Second Edition. California : SAGE Publications Inc (2000).

[24] Selden M., Goodie A.S. Social Network. Volume 52, pages 81-99 January (2018).

[25] Setiawan I. Jurnal Agrikultura Volume 19, Nomor 1 (2008).

[26] Utami D. Jaringan Komunikasi dan Informasi Harga dan Pemasaran Sayur [skripsi]. Bogor : Institut Pertanian Bogor (2013)

[27] Wahyuni S. Jaringan Komunikasi, Dinamika Kelompok dan Peningkatan Kapasitas Petani dalam Agribisnis Padi Organik [disertasi]. Bogor : Institut Pertanian Bogor (2016).

[28] Wahyuni S., Sumardjo, Lubis D.P., Sadono D. International Journal of Sciences: Basic and Applied Research (IJSBAR) 2016 Volume 28, No.2, pp 54-63 (2016).

[29] Wahyuni S., Sumardjo, Lubis D.P., Sadono D. Jurnal Penyuluhan, Maret 2017 Vol. 13 No.1 (2017).

[30] Wardyaningrum D. Jurnal Aspikom Vol 3. No 1 (2016).

[31] Yusi. Jurnal Ilmu Komunikasi. pp. 1-15 (2013).

[32] Zulkarnain. Analisis Hubungan Jaringan Komunikasi dengan Perubahan Taraf Penghidupan dan Pola Pikir dalam Pemberdayaan Pembudidaya Ikan di Kabupaten Kampar, Riau [disertasi]. Bogor Institut Pertanian Bogor (2015).

[33] Zulkarnain, Lubis D.P., Satria A, Hubeis M. Jurnal Sosek KP Vol. 10 No.1 $(2015$ 